\title{
Palmitate induces autophagy in pancreatic $\beta$-cells via endoplasmic reticulum stress and its downstream JNK pathway
}

\author{
YING-YING CHEN $^{1 *}$, LIAN-QING SUN $^{2 *}$, BAO-AN WANG $^{1}$, XIAO-MAN ZOU ${ }^{1}$, YI-MING MU ${ }^{1}$ and JU-MING LU ${ }^{1}$ \\ ${ }^{1}$ Department of Endocrinology, Chinese PLA General Hospital, Beijing 100853; ${ }^{2}$ Department of Traditional Chinese Medicine, \\ First Affiliated Hospital of Medical College of Xi'an Jiaotong University, Xi'an 710061, P.R. China
}

Received December 1, 2012; Accepted February 11, 2013

DOI: $10.3892 /$ ijmm.2013.1530

\begin{abstract}
Endoplasmic reticulum (ER) stress and autophagy have both been reported to be associated with lipotoxicity in $\beta$-cells, yet the relationship between them has not been fully clarified. In the present study, we tested the hypothesis that the ER stress-autophagic pathway in $\beta$-cells is a downstream pathway activated following saturated fatty acid treatment. Mouse insulinoma (MIN6) $\beta$-cells were treated with either palmitate or thapsigargin (TG) with or without various inhibitors. The results indicated that palmitate strongly enhanced the protein expression of microtubule-associated protein 1 light chain 3 (LC3)-II. Furthermore, the expression levels of ER stress markers, BiP and CHOP, and phosphorylation levels of JNK were increased after palmitate treatment. In addition, palmitate-induced autophagy was blocked by $500 \mu \mathrm{M}$ of the ER stress inhibitor tauroursodeoxycholic acid (TUDCA) or $20 \mu \mathrm{M} \mathrm{JNK}$ inhibitor SP600125. In turn, the phosphorylation of Akt (Ser473) was also downregulated by palmitate, while the levels of insulin receptor $\beta$ (IR $\beta$ ) were not reduced. A further increase in LC3-II levels was observed in cells treated with both palmitate and $50 \mu \mathrm{M}$ PI3K/Akt inhibitor LY294002 compared with cells treated with palmitate alone. Palmitate-induced phospho-Akt (Ser473) downregulation was also inhibited by TUDCA or SP600125. Pretreatment with the autophagy inhibitor 3-methyladenine (3-MA, $5 \mathrm{mM}$ ) for $1 \mathrm{~h}$ increased the expression of ER stress markers, and enhanced cell injuries caused by $0.1 \mu \mathrm{M}$ TG, including decreased cell viability and insulin secretion. Palmitate induces autophagy in pancreatic $\beta$-cells possibly through activation of ER stress and its downstream JNK pathway. Palmitate-induced autophagy may protect $\beta$-cells against cell injuries caused by ER stress.
\end{abstract}

Correspondence to: Professor Ju-Ming Lu, Department of Endocrinology, Chinese PLA General Hospital, 28 Fuxing Road, Haidian, Beijing 100853, P.R. China

E-mail: lujm301@163.com.cn

*Contributed equally

Key words: palmitate, lipotoxicity, autophagy, endoplasmic reticulum stress, $\beta$-cells

\section{Introduction}

Cell dysfunction induced by lipid accumulation or lipotoxicity in pancreatic $\beta$-cells may contribute to the pathogenesis of type 2 diabetes. In recent years, autophagy has been identified as a novel mechanism that regulates $\beta$-cell function (1-3) and death (4-6). Autophagy is a conserved self-digestion process among eukaryotes that regulates cellular component degradation through lysosomes. Autophagy plays an important role in maintaining cell homeostasis by regulating the synthesis, degradation and recycling of cellular components (7). A low level of constitutive autophagy exists in order to control the quality of proteins and organelles. Autophagy is important for survival as it reallocates nutrients to essential processes from less important ones (8). In addition, autophagy can also be induced under stress conditions to maintain the balance of the cell. Growing evidence $(4,9)$ indicates that autophagy in $\beta$-cells is activated by free fatty acids, and suggests that addressing the underlying mechanisms involved in lipid-induced autophagy may provide clues for treating or preventing $\beta$-cell lipotoxicity.

Free fatty acids are known as inducers of endoplasmic reticulum (ER) stress. Previous evidence has revealed that saturated fatty acid induces $\beta$-cell dysfunction and death via ER stress activation (10-13). Meanwhile, autophagy can also be activated by ER stress (14), and ER stress was reported to enhance autophagy by regulating the Akt/TSC/mTOR pathway (15). Thus, the possibility that lipidinduced autophagy acts as a downstream response to lipotoxic ER stress in $\beta$-cells is conceivable. The aim of this study was to verify saturated fatty acid-induced autophagy and to investigate the relationship between autophagy and ER stress.

\section{Materials and methods}

Reagents and antibodies. The following reagents were used. Palmitic acid, bovine serum albumin (BSA), bafilomycin A1, SP600125, LY294002, 3-methyladenine (3-MA), 3-(4,5-dimethylthiazole-2-yl)-2,5-diphenyltetrazolium bromide (MTT) and thapsigargin (TG) were purchased from SigmaAldrich Inc. (St. Louis, MO, USA). Tauroursodeoxycholic acid dihydrate (TUDCA) was obtained from Tokyo Chemical Industry Co. (Tokyo, Japan), and fetal bovine serum (FBS) and PageRuler ${ }^{\mathrm{TM}}$ Prestained ProteinLadder were both from Thermo Scientific (Rockford, IL, USA). The rat insulin 
radioimmunoassay (RIA) kit was from Linco Research, Inc. (St. Charles, MO, USA), and RIPA lysis buffer, complete protease inhibitor mixture, protein phosphatase inhibitor, and Super Enhanced chemiluminescence detection reagents were all from Applygen Technologies Inc. (Beijing, China). PVDF membranes were obtained from Millipore (Billerica, MA, USA), and the BCA protein assay kit was from KW Biotech (Beijing, China). The following antibodies were used: light chain 3 (LC3)A/B, BiP, CHOP, phospho-SAPK/JNK (Thr183/ Tyr185), SAPK/JNK, phospho-Akt (Ser473) and Akt (all from Cell Signaling Technology, Danvers, MA, USA). Actin, insulin receptor $\beta(\operatorname{IR} \beta)$, and the horseradish peroxidaseconjugated secondary antibody were purchased from Santa Cruz Biotechnology, Inc. (Santa Cruz, CA, USA).

Cell culture and palmitate preparation. Mouse insulinomaderived MIN6 cells were cultured in Dulbecco's modified Eagle's medium (DMEM, containing $25 \mathrm{mM}$ glucose) supplemented with $15 \% \mathrm{FBS}, 100 \mathrm{U} / \mathrm{ml}$ penicillin, $100 \mu \mathrm{g} / \mathrm{ml}$ streptomycin, $10 \mathrm{mM}$ HEPES, $2 \mathrm{mM}$ L-glutamine, $1 \mathrm{mM}$ sodium pyruvate and $5 \mu \mathrm{l} / 1 \beta$-mercaptoethanol at $37^{\circ} \mathrm{C}$ in a $5 \% \mathrm{CO}_{2} / 95 \%$ air atmosphere and $100 \%$ humidity. For detection of insulin secretion, the culture medium was replaced with DMEM containing $5.6 \mathrm{mM}$ glucose. Palmitic acid was dissolved in $0.1 \mathrm{~N} \mathrm{NaOH}$ at a concentration of $100 \mathrm{mM}$ and adjusted to $10 \mathrm{mM}$ palmitate with fatty acid-free BSA solution. The palmitate/BSA complex was then filtered and added to serum-free medium to achieve a final concentration of $0.5 \mathrm{mM}$ palmitate $/ 1 \% \mathrm{BSA}$.

Western blot analysis. The expression and phosphorylation levels of target proteins were detected by western blot analysis. Cells were lysed with RIPA lysis buffer containing complete protease inhibitor mixture and protein phosphatase inhibitor. After protein extraction, cell lysates were separated by sodium dodecyl sulfate polyacrylamide gel electrophoresis and transferred to PVDF membranes. Molecular weights were estimated by comparison with a prestained protein ladder. Nonspecific binding was blocked using 5\% skim milk. The membranes were then incubated with specific primary antibodies overnight at $4^{\circ} \mathrm{C}$. Subsequently, secondary antibody conjugated to horseradish peroxidase and Super Enhanced chemiluminescence detection reagents were used to detect the specific bands. Immunoblots were quantified by densitometric analysis using ImageTool 3.0 software. Quantification of protein phosphorylation was normalized with the corresponding total protein expression, and the relative expression level of a certain protein was normalized with actin. To visualize the accumulation of LC3-II, $20 \mathrm{nM}$ bafilomycin A1 was added to the culture medium during the final 4-h period. Bafilomycin A1, an inhibitor of vacuolar type $\mathrm{H}^{+}$-ATPase, inhibits the fusion of antophagosomes with lysosomes $(16,17)$.

Cell viability and morphological examination. Cell viability was determined using MTT assays following the experimental treatments. Briefly, cells were seeded in 96-well plates and incubated under different conditions. Then culture medium was removed, and $200 \mu \mathrm{l} /$ well diluted MTT solution $(0.5 \mathrm{mg}$ / $\mathrm{ml}$ ) was added to the culture. After a 4-h incubation at $37^{\circ} \mathrm{C}$, MTT solution in each well was replaced with $150 \mu$ ldimeth- ylsulfoxide (DMSO) to ensure that the crystals dissolved. After mixing, the absorbance was measured at $490 \mathrm{~nm}$ using a microplate reader. Cell viability was calculated as a percentage of absorbance. For morphological examination, cells were cultured in $6 \mathrm{~cm}$ plates and examined using light microscopy (x100).

Insulin secretion. Cells were seeded in 24-well plates at a density of $5 \times 10^{5}$ cells/well and incubated in different treatment media. After the indicated duration of culture, cells were washed with PBS and equilibrated in Kerbs-Ringer bicarbonate buffer (KRBB, $\mathrm{pH}$ 7.4) containing $118.5 \mathrm{mM}$ $\mathrm{NaCl}, 2.54 \mathrm{mM} \mathrm{CaCl}, 1.19 \mathrm{mM} \mathrm{KH}_{2} \mathrm{PO}_{4}, 4.74 \mathrm{mM} \mathrm{KCl}$, $1.19 \mathrm{mM} \mathrm{MgSO}, 25 \mathrm{mM} \mathrm{NaHCO}, 10 \mathrm{mM}$ HEPES, $0.5 \%$ BSA (fatty acid free) and $5.6 \mathrm{mM}$ glucose at $37^{\circ} \mathrm{C}$ for $30 \mathrm{~min}$. Then the buffer was removed and replaced with fresh KRBB containing 2.8 or $27.8 \mathrm{mM}$ glucose for $60 \mathrm{~min}$. The supernatants from cell cultures were collected, and the insulin concentration was measured using the insulin RIA kit after appropriate dilutions. The total protein was extracted with RIPA lysis buffer supplemented with $1 \mathrm{mM}$ phenylmethyl sulfonylfluoride, and then the concentration of the protein was determined using the BCA protein assay kit. The levels of insulin secretion were normalized with the respective protein content. Insulin secretion of the cells following stimulation with 2.8 and $27.8 \mathrm{mM}$ glucose was defined as basal insulin secretion (BIS) and glucose-stimulated insulin secretion (GSIS), respectively.

Statistical analysis. Data are expressed as means \pm SD. Statistical differences were determined using the Student's two-sample t-test or one-way ANOVA followed by the Student-Newman-Keuls test where appropriate, using SPSS 12.0 (SPSS Inc., Chicago, IL, USA). A P-value <0.05 was considered to indicate a statistically significant result.

\section{Results}

Palmitate upregulates autophagy via the ER stress-dependent $J N K$ pathway. To confirm palmitate-induced autophagy in $\beta$-cells, we detected the expression of LC3-II, a hallmark of autophagy activation (16), with or without $0.5 \mathrm{mM}$ palmitate for $36 \mathrm{~h}$. Western blot analysis showed that palmitate treatment significantly enhanced the LC3-II level when compared to the level in the control group (Fig. 1A). Meanwhile, MIN6 cells were cultured in $0.5 \mathrm{mM}$ palmitate for different times to determine whether ER stress and JNK phosphorylation were activated by palmitate. We found that the expression of ER stress markers, BiP and CHOP, and JNK phosphorylation were gradually increased following palmitate treatment (Fig. 1B). ER stress inhibitor TUDCA $(500 \mu \mathrm{M})$ and JNK inhibitor SP600125 $(20 \mu \mathrm{M})$ both exhibited an inhibitory effect on the palmitate-induced increase in LC3-II (Fig. 1C and D).

Involvement of Akt phosphorylation in palmitate-stimulated autophagy. We assessed the possible involvement of Akt phosphorylation in autophagy induction. First, we found that the insulin-induced p-Akt (Ser473) gradually decreased following palmitate treatment, while the expression of IR $\beta$ did not change within the 36-h treatment (Fig. 2A), indicating 

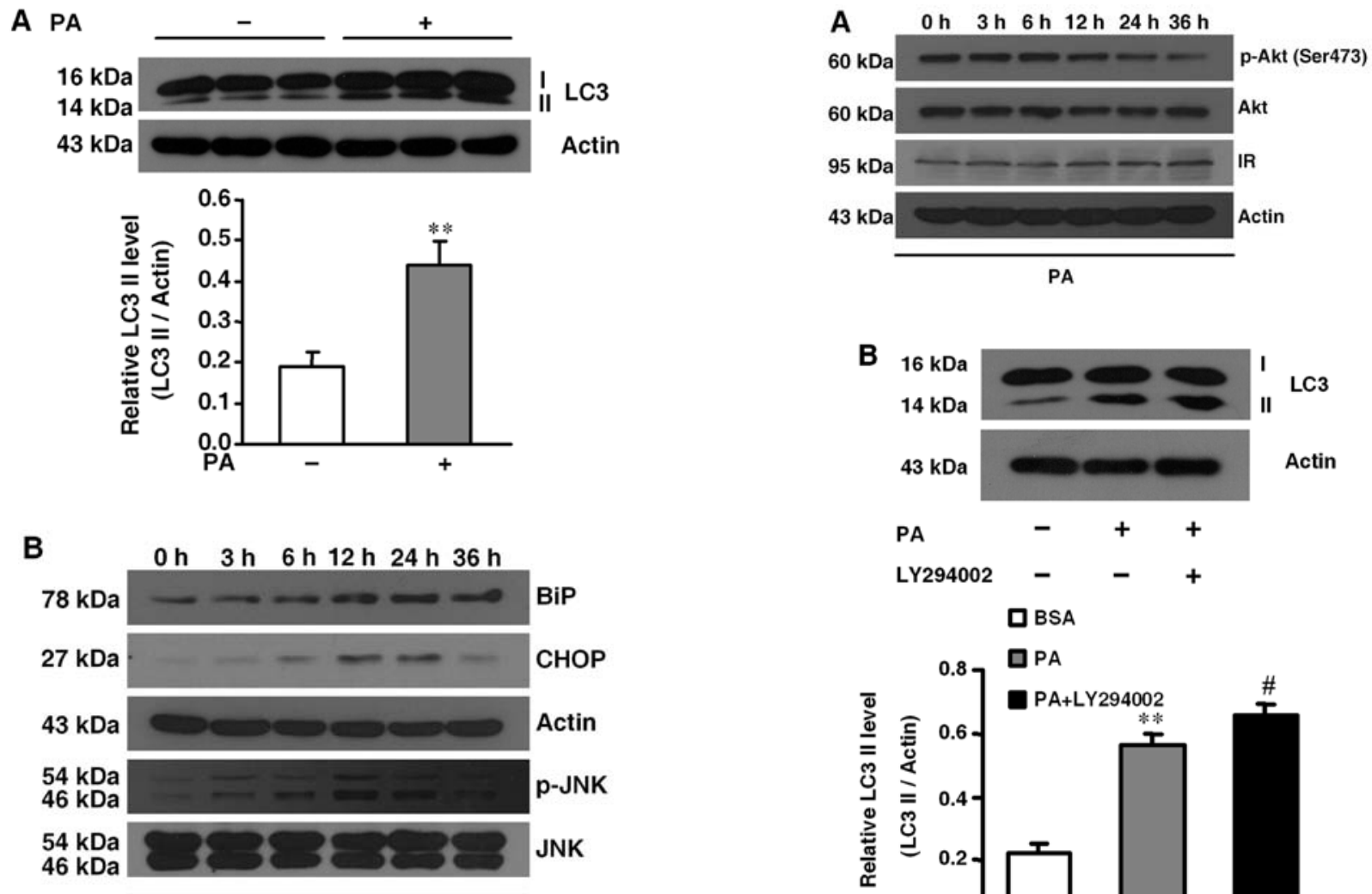

PA
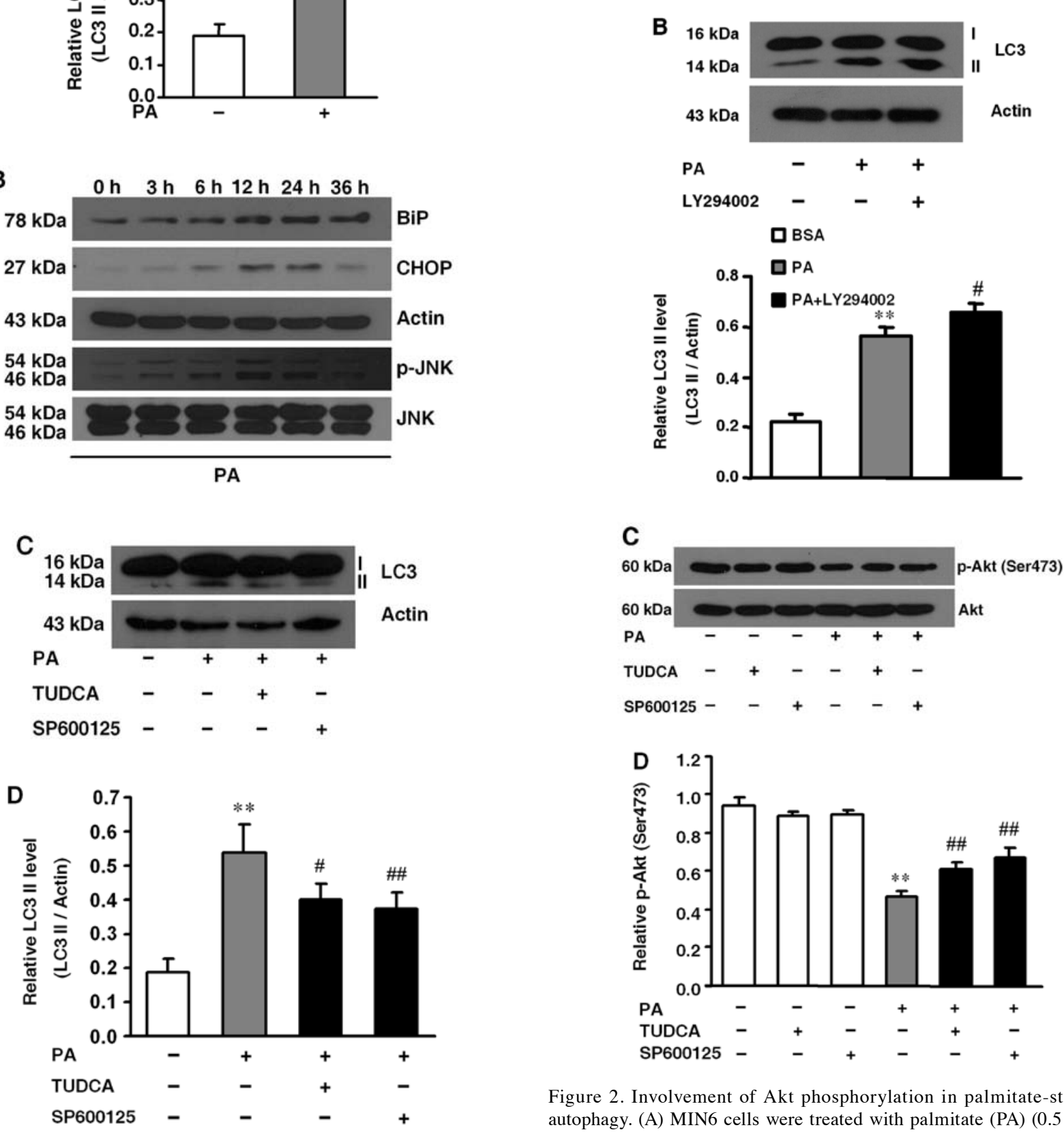

Figure 2. Involvement of Akt phosphorylation in palmitate-stimulated autophagy. (A) MIN6 cells were treated with palmitate (PA) $(0.5 \mathrm{mM})$ for the indicated times followed by stimulation with insulin $(100 \mathrm{nM})$ for $5 \mathrm{~min}$. Expression of p-Akt (Ser473) and IR $\beta$ was determined by immunoblotting. (B) MIN6 cells were treated as indicated for $36 \mathrm{~h}$. MIN6 cells were incubated in serum-free DMEM containing $1 \%$ BSA for $36 \mathrm{~h}$ as a negative control. LY294002 $(50 \mu \mathrm{M})$ enhanced the palmitate-induced increase in LC3-II. Bars in the histogram represent the mean $\pm \mathrm{SD}, \mathrm{n}=3 ;{ }^{* *} \mathrm{P}<0.01$ vs. control, ${ }^{*} \mathrm{P}<0.05$ vs. PA group. (C) Effects of TUDCA $(500 \mu \mathrm{M})$ and SP600125 $(20 \mu \mathrm{M})$ on the PA-induced decrease in p-Akt. MIN6 cells were incubated in serum-free DMEM containing $1 \%$ BSA for $36 \mathrm{~h}$ as BSA control group. The other groups were treated as indicated for $36 \mathrm{~h}$. The cells were then treated with insulin $(100 \mathrm{nM})$ for $5 \mathrm{~min}$. Both reagents suppressed the PA-induced reduction in p-Akt (Ser473). (D) The relative p-Akt (Ser473) levels were quantified following the different treatments. Bars represent the mean $\pm \mathrm{SD}, \mathrm{n}=3 ;{ }^{* *} \mathrm{P}<0.01$ vs. BSA control; ${ }^{\# /} \mathrm{P}<0.01$ vs. PA group. 


\section{A}

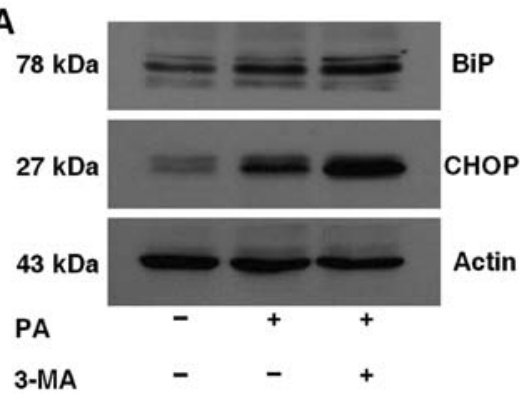

B

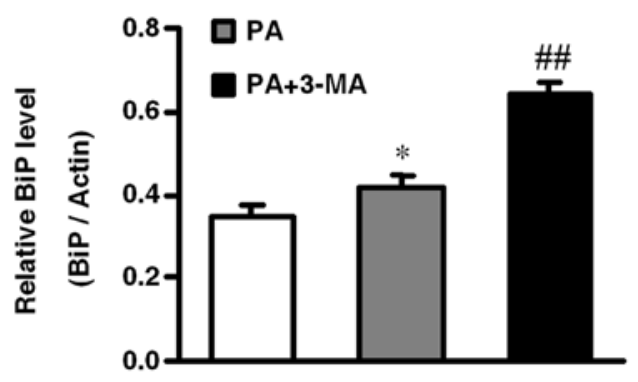

C

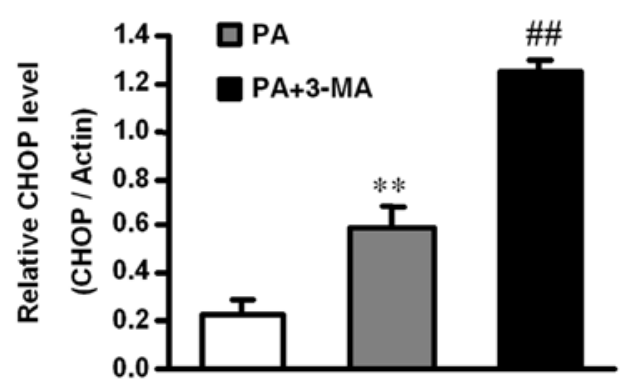

Figure 3. Inhibition of autophagy aggravates palmitate-induced ER stress. (A) MIN6 cells were pretreated with or without 3-MA (5 mM) for $1 \mathrm{~h}$ followed by treatment with or without PA $(0.5 \mathrm{mM})$ for $24 \mathrm{~h}$. Expression of $\mathrm{BiP}$ and $\mathrm{CHOP}$ was determined by immunoblotting. (B) The relative BiP levels were quantified following the different treatments. Bars represent the mean $\pm \mathrm{SD}, \mathrm{n}=3 ;{ }^{*} \mathrm{P}<0.05$ vs. BSA control; ${ }^{\# \#} \mathrm{P}<0.01$ vs. PA group. (C) The relative $\mathrm{CHOP}$ levels were quantified following the different treatments. Bars represent the mean $\pm \mathrm{SD}, \mathrm{n}=3 ;{ }^{* * *} \mathrm{P}<0.01$ vs. BSA control; ${ }^{\# \#} \mathrm{P}<0.01$ vs. PA group.

that palmitate induced a reduction in $\mathrm{p}-\mathrm{Akt}$ independent of the insulin receptors. Next, to investigate the role of p-Akt reduction, we suppressed the PI3K/Akt pathway using LY294002. LY294002 $(50 \mu \mathrm{M})$ was found to facilitate palmitate-induced autophagy by increasing LC3-II expression (Fig. 2B). We also investigated the upstream reduction in p-Akt and found that both TUDCA $(500 \mu \mathrm{M})$ and SP600125 $(20 \mu \mathrm{M})$ inhibited the palmitate-induced reduction of p-Akt (Fig. 2C and D). Our results suggest an involvement of decreased Akt phosphorylation in palmitate-induced autophagy through ER stress and JNK activation.

Inhibition of autophagy aggravates palmitate-induced ER stress. To examine the effect of autophagy inhibition on ER stress, MIN6 cells were pretreated with or without $5 \mathrm{mM}$ 3-MA for $1 \mathrm{~h}$ and then treated with $0.5 \mathrm{mM}$ plamitate for
A
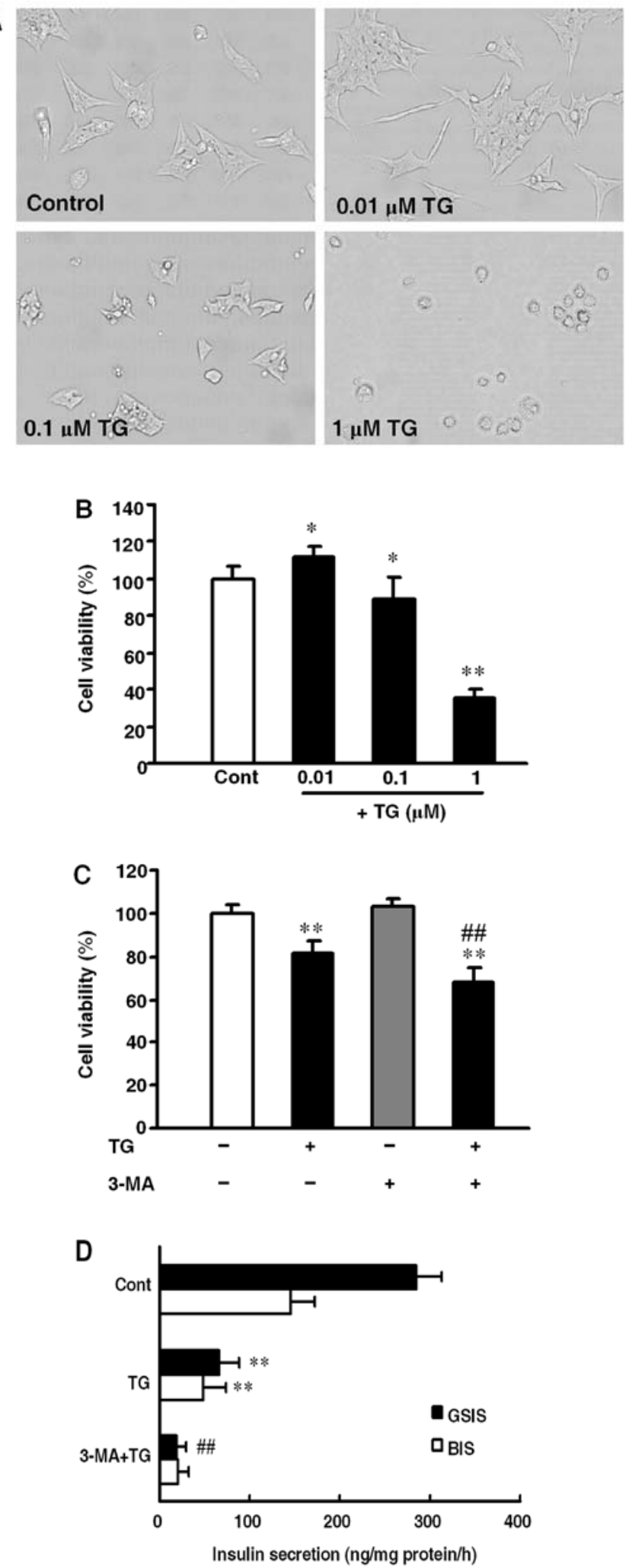

Figure 4. Inhibition of autophagy aggravates cell injuries caused by ER stress. (A) Morphology of MIN6 cells treated with different doses of TG for $36 \mathrm{~h}$ and examined using light microscopy (x100). (B) Cell viability of MIN6 cells treated with different doses of TG for $36 \mathrm{~h}$ by MTT assay. Bars represent the mean $\pm \mathrm{SD}, \mathrm{n}=6 ;{ }^{*} \mathrm{P}<0.05,{ }^{* *} \mathrm{P}<0.01$ vs. control group. (C) Cells were pretreated with or without 3-MA $(5 \mathrm{mM})$ for $1 \mathrm{~h}$, and then incubated in the presence or absence of TG $(0.1 \mu \mathrm{M})$ for $36 \mathrm{~h}$. Bars represent the mean $\pm \mathrm{SD}$, $\mathrm{n}=6 ;{ }^{* *} \mathrm{P}<0.05$ vs. control group; ${ }^{\# \#} \mathrm{P}<0.01$ vs. TG group. (D) Pretreatment with 3-MA enhances the TG-induced reduction in insulin secretion. Insulin levels were determined using the insulin RIA kit and normalized with the respective protein content. Bars represent the mean $\pm \mathrm{SD}, \mathrm{n}=8 ;{ }^{* * *} \mathrm{P}<0.05$ vs. control group; ${ }^{\# \#} \mathrm{P}<0.01$ vs. TG group. 


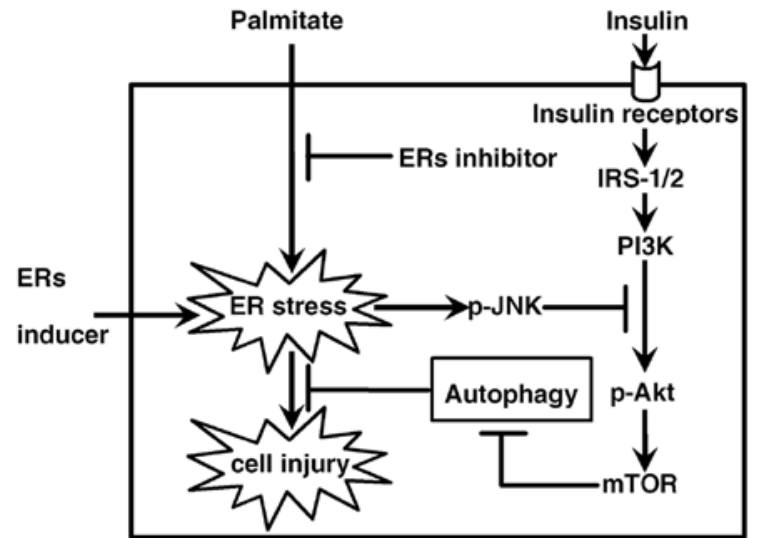

Figure 5. Model of the pathway of palmitate-induced autophagy in $\beta$-cells. Palmitate stimulates autophagy via ER stress and its downstream JNK phosphorylation. The palmitate-induced reduction in Akt phosphorylation through ER stress and JNK activation is involved in palmitate-stimulated autophagy. Inhibition of autophagy aggravates palmitate-induced ER stress and cell injuries caused by ER stress.

36 h. As shown in Fig. 3, the expression of ER stress markers, $\mathrm{BiP}$ and $\mathrm{CHOP}$, was increased by 3-MA pretreatment.

Inhibition of autophagy aggravates cell injuries caused by ER stress. As shown in Fig. 4A and B, TG caused cell injury in MIN6 cells in a dose-dependent manner. A concentration of $0.1 \mu \mathrm{M}$ TG was chosen for use in the subsequent experiments. MTT assay revealed that treatment with $0.1 \mu \mathrm{M}$ TG for $36 \mathrm{~h}$ decreased the cell viability of MIN6 cells from 100.0 \pm 4.1 to $81.4 \pm 6.0 \%$, while pretreatment with 3 -MA followed by $0.1 \mu \mathrm{M}$ TG caused a further decrease to $68.2 \pm 6.1 \%$ (Fig. 4C). TG also inhibited insulin secretion, including BIS from $145.96 \pm 25.65$ to $48.38 \pm 25.47 \mathrm{ng} / \mathrm{mg}$ protein/h and GSIS from $285.14 \pm 28.03$ to $65.62 \pm 22.81 \mathrm{ng} / \mathrm{mg}$ protein $/ \mathrm{h}$. Compared with TG alone, TG exposure following 3-MA pretreatment significantly reduced insulin secretion to a greater extent, with a BIS value of $21.26 \pm 10.66 \mathrm{ng} / \mathrm{mg}$ protein/h and a GSIS value of $19.42 \pm 9.32 \mathrm{ng} / \mathrm{mg}$ protein/h, respectively (Fig. 4D).

\section{Discussion}

In the present study, we examined the molecular mechanisms of lipid-induced autophagy in $\beta$-cells. In accordance with previous studies $(4,9)$, enhancement of LC3-II levels, a marker of autophagy, was observed following palmitate treatment. Palmitate-induced autophagy is considered to be a ubiquitous process, as autophagy was also confirmed to be induced in several other cell lines (9). The possible involvement of ER stress and the JNK pathway was examined to further understand the mechanisms of palmitate-induced autophagy. The results showed that the expression of ER stress markers and p-JNK was gradually increased in conjunction with prolonged treatment time of palmitate. In addition, TUDCA and SP600125 were used to further verify whether ER stress and JNK are associated with palmitate-induced autophagy. TUDCA is a type of chemical chaperone which can effectively alleviate ER stress (18), and SP600125 is widely used as a JNK-specific inhibitor. Results showed that palmitate-induced autophagy was blocked both by TUDCA and by SP600125, suggesting that ER stress and JNK do participate in the induction of autophagy. The concept that the JNK pathway plays a role in palmitate-induced autophagy was also proven in another study (9), and it was shown that ER stress-related JNK activation was mediated by ER stress marker IRE1 $(14,19)$.

Since JNK activation was reported to take part in the suppression of insulin signaling by inducing serine phosphorylation of insulin receptor substrate-1 (20), we also examined the effect of palmitate on insulin-induced phosphorylation of Akt, a downstream target of insulin signaling. As shown in Fig. 2A, insulin-induced Akt phosphorylation was reduced following palmitate treatment, and this reduction was independent of the change in IR $\beta$ expression. Moreover, the downregulation of Akt phosphorylation was associated with ER stress and JNK phosphorylation, as TUDCA and SP600125 treatment blocked the decrease in Akt phosphorylation level caused by palmitate. Previously, the concept of $\beta$-cell insulin resistance has been discussed $(21,22)$. The reduction in insulin-induced Akt phosphorylation here was a result of an alteration in the insulin signaling cascade, and may be considered as a sign of $\beta$-cell insulin resistance. LY294002 was found to be a specific PI3K inhibitor for suppressing the activation of the PI3K-Akt-mTOR axis (23). Following the use of LY294002, the level of autophagy induced by palmitate was further increased, indicating the involvement of Akt in the formation of palmitate-induced autophagy. Notably, palmitate is the precursor of ceramide, and ceramide was shown to stimulate autophagy by inhibiting Akt phosphorylation (24). Furthermore, the control of autophagy is characterized by the necessity of class-III PI3K for autophagosome formation or by being inhibited by class-I PI3K/Akt/mTOR $(25,26)$. Although reduced insulin signaling was reported to accompany pancreatic $\beta$-cell dysfunction (27), we believe that autophagy and its upstream reduction in insulin signaling act as adaptive and protective responses to ER stress.

Inhibition of autophagy by 3-MA, a widely used inhibitor of autophagic flux, facilitated the induction of ER stress by palmitate. TG is known as a chemical which can induce ER stress by inhibiting ER $\mathrm{Ca}^{2+}$-ATPase (28). We also found that cell injuries caused by TG were further aggravated by 3-MA pretreatment, including a decrease in cell viability and insulin secretion.

In summary, our results revealed that ER stress, its downstream JNK pathway and the inhibition of insulin signaling contributed to palmitate-induced autophagy. A model of the pathway is proposed in Fig. 5. A reduction in autophagy aggravated ER stress and related cell injuries. If autophagy is elevated in type 2 diabetes, one could speculate that the onset of autophagy under stress conditions may be an adaptive response intended to protect $\beta$-cells against damage.

\section{References}

1. Fujitani Y, Ebato C, Uchida T, Kawamori R and Watada H: $\beta$-cell autophagy: a novel mechanism regulating $\beta$-cell function and mass: lessons from $\beta$-cell-specific Atg7-deficient mice. Islets 1: 151-153, 2009.

2. Ebato C, Uchida T, Arakawa M, Komatsu M, Ueno T, Komiya K, Azuma K, et al: Autophagy is important in islet homeostasis and compensatory increase of beta cell mass in response to high-fat diet. Cell Metab 8: 325-332, 2008. 
3. Jung HS, Chung KW, Won Kim J, Kim J, Komatsu M, Tanaka K, Nguyen YH, et al: Loss of autophagy diminishes pancreatic beta cell mass and function with resultant hyperglycemia. Cell Metab 8: 318-324, 2008.

4. Choi SE, Lee SM, Lee YJ, Li LJ, Lee SJ, Lee JH, Kim Y, et al: Protective role of autophagy in palmitate-induced INS-1 beta-cell death. Endocrinology 150: 126-134, 2009.

5. Fujimoto K, Hanson PT, Tran H, Ford EL, Han Z, Johnson JD Schmidt RE, et al: Autophagy regulates pancreatic beta cell death in response to Pdx 1 deficiency and nutrient deprivation. J Biol Chem 284: 27664-27673, 2009.

6. Masini M, Bugliani M, Lupi R, del Guerra S, Boggi U, Filipponi F, Marselli L, et al: Autophagy in human type 2 diabetes pancreatic beta cells. Diabetologia 52: 1083-1086, 2009.

7. Levine B and Klionsky DJ: Development by self-digestion: molecular mechanisms and biological functions of autophagy. Dev Cell 6: 463-477, 2004.

8. Kuma A, Hatano M, Matsui M, Yamamoto A, Nakaya H, Yoshimori T, Ohsumi Y, et al: The role of autophagy during the early neonatal starvation period. Nature 432: 1032-1036, 2004.

9. Komiya K, Uchida T, Ueno T, Koike M, Abe H, Hirose T, Kawamori R, et al: Free fatty acids stimulate autophagy in pancreatic $\beta$-cells via JNK pathway. Biochem Biophys Res Commun 401: 561-567, 2010

10. Karaskov E, Scott C, Zhang L, Teodoro T, Ravazzola M and Volchuk A: Chronic palmitate but not oleate exposure induces endoplasmic reticulum stress, which may contribute to INS-1 pancreatic beta-cell apoptosis. Endocrinology 147: 3398-3407, 2006.

11. Cnop M, Igoillo-Esteve M, Cunha DA, Ladrière L and Eizirik DL: An update on lipotoxic endoplasmic reticulum stress in pancreatic beta-cells. Biochem Soc Trans 36: 909-915, 2008.

12. Lai E, Bikopoulos G, Wheeler MB, Rozakis-Adcock M and Volchuk A: Differential activation of ER stress and apoptosis in response to chronically elevated free fatty acids in pancreatic beta-cells. Am J Physiol Endocrinol Metab 294: E540-E550, 2008.

13. Cnop M, Ladrière L, Igoillo-Esteve M, Moura RF and Cunha DA: Causes and cures for endoplasmic reticulum stress in lipotoxic $\beta$-cell dysfunction. Diabetes Obes Metab 12: 76-82, 2010.

14. Ogata M, Hino S, Saito A, Morikawa K, Kondo S, Kanemoto S, Murakami T, et al: Autophagy is activated for cell survival after endoplasmic reticulum stress. Mol Cell Biol 26: 9220$9231,2006$.
15. Qin L, Wang Z, Tao $\mathrm{L}$ and Wang $\mathrm{Y}$ : ER stress negatively regulates AKT/TSC/mTOR pathway to enhance autophagy. Autophagy 6: 239-247, 2010.

16. Mizushima $\mathrm{N}$ and Yoshimori T: How to interpret LC3 immunoblotting. Autophagy 3: 542-545, 2007.

17. Klionsky DJ, Elazar Z, Seglen PO and Rubinsztein DC: Does bafilomycin A1 block the fusion of autophagosomes with lysosomes? Autophagy 4: 849-950, 2008.

18. Ozcan U, Yilmaz E, Ozcan L, Furuhashi M, Vaillancourt E, Smith RO, Görgün CZ, et al: Chemical chaperones reduce ER stress and restore glucose homeostasis in a mouse model of type 2 diabetes. Science 313: 1137-1140, 2006.

19. Urano F, Wang X, Bertolotti A, Zhang Y, Chung P, Harding HP and Ron D: Coupling of stress in the ER to activation of JNK protein kinases by transmembrane protein kinase IRE1. Science 287: 664-666, 2000.

20. Hirosumi J, Tuncman G, Chang L, Görgün CZ, Uysal KT, Maeda K, Karin M, et al: A central role for JNK in obesity and insulin resistance. Nature 420: 333-336, 2002.

21. Leibiger IB, Leibiger B and Berggren PO: Insulin signaling in the pancreatic beta-cell. Annu Rev Nutr 28: 233-251, 2008.

22. Kahn CR, Brüning JC, Michael MD and Kulkarni RN: Knockout mice challenge our concepts of glucose homeostasis and the pathogenesis of diabetes mellitus. J Pediatr Endocrinol Metab 13: $1377-1384,2000$.

23. Wu YT, Tan HL, Huang Q, Ong CN and Shen HM: Activation of the PI3K-Akt-mTOR signaling pathway promotes necrotic cell death via suppression of autophagy. Autophagy 5: 824-834, 2009.

24. Scarlatti F, Bauvy C, Ventruti A, Sala G, Cluzeaud F, Vandewalle A, Ghidoni R, et al: Ceramide-mediated macroautophagy involves inhibition of protein kinase $\mathrm{B}$ and up-regulation of beclin 1. J Biol Chem 279: 18384-18391, 2004.

25. Meijer AJ and Codogno P: Macroautophagy: protector in the diabetes drama? Autophagy 3: 523-526, 2007.

26. Leibowitz G, Cerasi E and Ketzinel-Gilad M: The role of mTOR in the adaptation and failure of beta-cells in type 2 diabetes. Diabetes Obes Metab 10: 157-169, 2008.

27. Matsuda T, Kido Y, Uchida T and Kasuga M: Reduced insulin signaling and endoplasmic reticulum stress act synergistically to deteriorate pancreatic beta cell function. Kobe J Med Sci 54 : E114-E121, 2008.

28. Ozcan U, Cao Q, Yilmaz E, Lee AH, Iwakoshi NN, Ozdelen E, Tuncman G, et al: Endoplasmic reticulum stress links obesity, insulin action, and type 2 diabetes. Science 306: 457-461, 2004. 